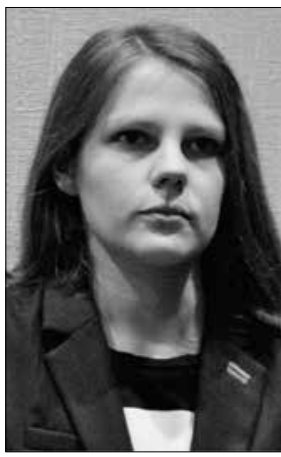

MIGLE் MUNDERZBAKAITE்

Vytauto Didžiojo universitetas, Lietuva

Vytautas Magnus University, Lithuania

\title{
ADAPTACIJŲ STUDIJOS: ANALIZĖS METODAI IR VERTINIMO KRITERIJAI
}

\author{
Adaptation Studies: Analytical Methods and Assessment Criteria
}

\author{
SUMMARY
}

No matter what the intention of adaptation is - creation of it or an attempt to analyse it - Andreas Bazin is usually mentioned. Bazin was a French film critic and theorist. He initiated the famous film reflection magazine "Cahiers du Cinema" (first publication 1951) and wrote "Adaptation or the Cinema as Digest" (1948). In the article the author started talking about adaptations of cinema: the principles of creation, the position of text in relation with the new work, the meaning of adaptation and its impact on film audiences. While using an example of an exposition in a museum, he explains adaptation. We see selected collections of paintings in galleries but we do not doubt the value and originality of these works. Since the middle of the $20^{\text {th }}$ century, the evaluation of adaptation, methods of analysis and access changed. With some reservations, however, the focus of analysis remains on the text (narrative of the adaptation work). This article presents the field of adaptation research, its trends, the dominant context for evaluation criteria, most commonly used methods and tools of analysis. Post-structuralism had a big influence on adaptation research. It "borrowed" some important ideas: the formation of the phenomena of intertextuality and intermediality and deconstructive access.

\section{SANTRAUKA}

Kad ir kaip toli siektų adaptacijos ištakos - jụ kūrimas, bandymas analizuoti, tačiau adaptacijos studijų pradžia, atskaitos taškas, pirmos profesionalios įžvalgos, paskatinusios tolesnius tyrimus, paprastai siejamos su prancūzų kino kritiku ir teoretiku Andre Bazinu ir jo straipsniu "Adaptacija arba kinas kaip santrauka" (1948). Straipsnyje autorius pradèjo kalbèti apie kino adaptacijas: ju kūrimo principus, teksto poziciją naujo kūrinio atžvilgiu, adaptacijų reikšmę ir poveikį kino žiūrovams. Nuo XX a. vidurio adaptacijų vertinimas, ju analizavimo metodai, prieigos keitėsi, tačiau su tam tikromis išlygomis analizės centras tebėra tekstas (adaptuojamo kūrinio naratyvas). Šiame straipsnyje aptariamas adaptacijų tyrimų laukas, jo kryptys, dominuojantis vertinimo kriterijų kontekstas, dažniausiai taikomi analizės metodai, ̨rankiai.

RAKTAŽODŽIAI: adaptacija, naratyvas, dekonstrukcija, intermedialumas, intertekstualumas. KEY WORDS: adaptation, narrative, deconstruction, intermediality, intertextuality. 


\section{ADAPTACIJOS: ANALIZĖS KRYPTYS}

Ivairiose studijose egzistuoja bent trys pagrindinès adaptaciju , be abejo, tarpusavyje susijusiu, kryptys. Pirmoji siejama su teoriniu adaptacijos studiju lauko klausimų sprendimu, tokių kaip, koks kūrinys laikytinas adaptacija - ar kiekvienas, kuriame egzistuoja pirminis rašytinis tekstas, konvertuojamas i kitos medijos kalba, ar tik toks, kuriame, nors ir panaudojant vieną originalaus teksto sakini, atsižvelgiama ì rašytojo kūrinį; naujai sukurto kūrinio adaptacijos vieta pirminio teksto atžvilgiu; vis dar egzistuojančios hierarchijos problemiškumas; ištikimybès tekstui siekiniai; nusistovèjusios bei naujai siūlomos "taisyklès" adaptuojamiems kūriniams; mediju tarpusavio sąveika; adaptacijų klasifikacijos.

Antroji kryptis, susieta su adaptacijomis kaip kūrybos industrijos dalimi, analizuojamas komercinis aspektas: ekonominiai, teisiniai reikalai. Viena iš šios krypties analizuotinų temų - sejkmingu literatūros kūrinių perkèlimas ị vizualią mediją kaip sėkmės garantas arba sèkminga adaptacija išnaudojama kaip galimybė adaptacijoms kitose medijose, kitais išraiškos būdais (teminiai parkai, kompiuteriniai žaidimai ir kt.). Taip pat atsižvelgiama į dažnai aktualią autorinių teisių problemą. Simone Murray atmeta
M. Foucault, R. Bartheso skleistą ,"autoriaus mirties" idèją ir kalba apie kultūrinį kapitalą, kuri industrija suteikia autoriui. Kuo autorius garsesnis, didesni jo laimèjimai, tuo daugiau igyja jo kūrinys pranašumu, kurie, tikètina, paspartina jo adaptacijos procesą ${ }^{1}$. Autorè iškelia reikšmingus adaptacijos klausimus, analizuotinas temas, pavyzdžiui: autorystès - nuo autoriaus kaip ižzymybès figūros iki autoriaus kaip prekès ženklo; agentų (tarpininkų) pozicija tarp rašytojų ir leidejjų bei platesniame mediju kontekste; sąmoningi, organizuoti literatūros, kino ir kitų medijų kūrëjų susitikimai kaip platforma naujai produkcijai; „Bukerio premija” („Booker Prize”), kurios laimètojo kūrinys pretenduoja i adaptacijos sukūrimą.

Trečioji labiau susijusi su adaptaciju istorija, akademine kritika, vertinimais. Kaip keičiasi adaptacijų skirstymai; kiek pirminio teksto pokyčius adaptacijoje lemia režisierių kūrybos laikotarpis, kontekstas; kokiomis aplinkybėmis renkamasi adaptuoti klasikinius kūrinius, kodèl gana retai imamasi šiuolaikinių literatūros kūrèjų; kas lemia ištikimos transformacijos (D. Andrew sąvoka) adaptacijų vertinimą ar sieki dekonstruoti pirmini tekstą.

\section{VERTINIMO KRITERIJAI}

Ivairiose medijose sukurtų adaptacijų vertinimo kriterijai svyruoja nuo kūrinio „dvasios“ perkèlimo (kino teoretiko Andre Bazino îvardinta sąvoka) ì kitą mediją siekio kuo tiksliau adaptuoti kūrinį, iki kito kraštutinumo - nuolatinio tikslo pasirinktą kūrinį-tekstą suaktualinti: pritaikyti ji konkrečiam laikotarpiui, vietai ar erdvei; pateikti kuo netikèčiausią kūrinio perskaitymo rakursa, kontroversiš- 
ką jo versiją besipriešinančią nusistovèjusioms kūrinio interpretacijoms.

Vis dažniau įvertinamas režisierių bandymas kurti adaptacijas, apimančias kelis to paties autoriaus kūrinius, adaptacija tampa tam tikru kūrinių koliažu, autoriaus tekstų retrospektyva (kartais itraukiant ir pati autoriu, jo biografiją arba ji pati kaip pasakotojo balsą). Adaptacijų analizėse neretai skeptiškai žiūrima i̇ režisierius, kuriančius beveik pažodines klasikinių kūrinių adaptacijas, pradedama abejoti ju profesionalumu, atsiranda hipotezè apie tokių autoriu bandymą pasinaudoti pirminio teksto autoriaus žinomumu ir taip pasiekti platesnes auditorijas neįdedant į naują kūrinį nieko daugiau, kas leistų pamatyti režisieriaus profesionaluma, jo požiūrị, intencijas adaptuojamo kūrinio atžvilgiu. Arba, kitaip sakant, skeptiškai pradedama žiūrèti i Th. Leitcho įvardintas muziejines adaptacijas (curratorial adaptations) ${ }^{2}$.

Skaitant kritines adaptacijų refleksijas, galima įžvelgti ir tam tikrus dèsningumus kalbant apie klasikinès ir šiuolaikinès literatūros adaptavimą. Beveik taisykle, su nedidelèmis išimtimis, tampa šiuolaikinès literatūros adaptavimas ir sukurtu adaptacijų analizavimas, vertinimas. Galima išskirti kelis variantus. Pirma, adaptuojama šiuolaikinè literatūra, dažniausiai pripažistant jos aktualumą, todèl neretai atliekamos menkos interpretacijos: kupiūravimai ar papildymai dèl pritaikymo konkrečiam lokaliam kontekstui. I š šiuolaikinę nacionalinę literatūra, koncentruojantis ị lietuviškaji konteksta, žvelgiama labai atsargiai, vis dažnesnis tampa režisieriu ir rašytoju bendradarbiavimas. Tuomet dažnai sce- ninės adaptacijos autorystė susiniveliuoja, tekstas tampa tarsi bendru kūrybinès komandos bendradarbiavimo rezultatu, kurio vertinimas iš adaptaciju perspektyvos būna komplikuotas.

Adaptacijų vertinimo kriterijai iš tikrujju yra labai priklausomi ir nuo konkrečios medijos, kurioje adaptuojamas tekstas (nors nebūtinai). Netgi tos pačios medijos erdvèje galima pastebèti ir tam tikriems žanrams, formoms būdingus aspektus, aktualizuojamus analizuojant sukurtas adaptacijas. Pavyzdžiui, teatro medijoje, dramos teatre, sukurta adaptacija neretai sulaukia glaudesnio santykio su tekstu nagrinèjimo, o operos ir baleto teatre sukurto spektaklio analizè neretai grižta prie anksčiau suformuluoto teksto "dvasios“, jos paieškos kūrinyje arba / ir prie paties kūrèjo, jo sukurtos stilistikos, apskritai kūrinių atmosferos perkèlimo, transformavimo scenai (šokio spektakliui). Kino medijoje iš vaidybinio kino, panašiai kaip ir iš dramos spektaklio, tikimasi detalesnio kūrinio perkèlimo, vertinamos konkrečios personažu ivykiu, aplinkybiu interpretacijos. Kino animacijoje kuriamos adaptacijos ilgą laiką (neretai ir dabar) vertinamos kaip fragmentiškas, supaprastintas kūrinio perkèlimas i kino ekraną, turintis informacinę funkcija, dažnai skirtą vaikų auditorijai. Tokiais atvejais svarbu sklandus, išgrynintas pasakojimas, dažnai iš daugiasluoksnio kūrinio paliekant vieną vyraujančią siužetinę linija, galinčią parodyti ne platesnị interpretacijų lauką, o daugiau pramoginę, edukacinę funkciją. Yra sukurta daugybė adaptacijų, skirtu būtent skatinti klasikinių kūrinių supratima, susidomejjimą jais, tačiau ju reikšmè vertinama itin kontroversiškai. 
Adaptaciju, studiju kontekste vis dar gana retai analizuojamos kitos adaptacijos formos, daugiausia pasižyminčios interaktyvumu, pavyzdžiui, kompiuteriniai žaidimai, teminiai parkai. Jos vei- kia tarsi tik kaip šalutinis adaptaciju produktas, kaip komercinè jų dalis, turinti aišku tikslą - didinti pirmujuų, dažniausiai stambių kino kompaniju prodiusuotų filmų, adaptacijų populiarumą.

\section{ADAPTACIJŲ ANALIZĖS METODAI}

\section{Pamatinė prieiga:}

naratyvinè analizė

Analizuojant adaptacijas yra keletas dažniausiai naudojamų teorinių prieigu, metodų. Viena iš analizės perspektyvų tai naratyvinè analizè. Irina Melnikova, aptardama Briano McFarlane'o izžvalgas, teigia: „Naratyvas - transmedialioji (su medijos specifika nesusijusi) kategorija, siejanti dažniausiai ekranizuojamus pasakojamosios literatūros tekstus ir kiną. Ir literatūra, ir kinas pasakoja istorijas kuria naratyvus. „Tą pačią“" istoriją galima papasakoti kitos medijos priemonėmis. Tad adaptacijos atveju naratyvo struktūra gali būti naujai reprezentuojama naujoje "tikrovejje" remiantis ekvivalentais, rastais kino terpejje. ${ }^{\text {/3 }}$ Naratyvo apibrèžimas, siūlomas Gabrielès Labanauskaitės („Naratyvas turi detaliai atpasakoti įvyki ar ivvykius, kitaip jis bus laikomas ne naratyvu, o aprašymu. Naratyvo reprezentacijos būdas gali būti ivvairus: žodinis, užrašytas, perteiktas ženklų kalba (judantys arba statiški paveikslèliai), gestai, muzika ar bet kuri minètų būdų kombinacija. Taip pat jis gali igyti iqvairias formas - romanų, noveliu, istoriniu veikalu, autobiografiju ir biografiju, epu, mitu, liaudies pasaku, legendų, baladžių, naujienų pranešimų, filmu, spektakliu ir t. t." ${ }^{4}$, papildo B. McFarlane'o izžvalgas keliomis idejo- mis: naratyvą kaip priemonę ir metodą adaptacijų analizių autoriai dažniausiai renkasi, nes jis egzistuoja daugelyje skirtingu mediju bei yra labai detalus, „gilus" analizuojamo kūrinio adaptacijos atžvilgiu. Naratyvinė analizė, kaip ir adaptacijos teorija, gali tureti skirtingu analizès metodu, modeliu, kurie nužymi pagrindinį atliekamos analizès tikslą. Pavyzdžiui, Elliotas Mishleris siūlo tris plačias kategorijas: pirmajai priskiria analizès modelius, kurie padeda susitelkti prie perteikiamo pasakojimo, istorijos teisingumo; antrajai - metodus, kurie koncentruojasi prie tekstų sąsajų ir struktūros; trečioji analizès modelių kategorija susiejama su pasakojimo kontekstais, ju pasekmiu funkcija ${ }^{5}$. Nepaisant šiuolaikiniame kontekste vis didèjančio adaptacijų, ryškiai nutolstančiu nuo pradinio šaltinio, naudojančių tik jo motyvus, skaičiaus, naratyvinè analizė dominuoja kritinių refleksiju, recenziju diskurse.

\section{Intertekstualumas}

Poststruktūralizmo teorijos lauke susiformavo daugelyje sričiu aktualus intertekstualumo terminas, susijęs su tekstiniais ryšiais. Paprastai išskiriamos dvi intertekstualumo sampratos. Anot Irinos O. Rajewsky, , viename spektro gale platus, universalus intertekstualumo supratimas pirmiausia siejamas su prancūzu 
poststruktūralizmu. Sekdama M. Bachtino dialogo (dialogiškumo) koncepcija, Julia Kristeva suformulavo intertekstualumo samprata, apimančią visas kultūrines praktikas. Kitame spektro gale yra siauresnè intertekstualumo koncepcija kaip kategorija specifinių tekstų analizei, supratimui..." ${ }^{\prime 6}$ Iš esmès J. Kristevos teorija grindžiama požiūriu, kad „bet koks tekstas yra intertekstas, nes rašomas skaitant kitus tekstus, tad kiekvienas žodis yra kitų žodžių susikirtimas, kiekviena struktūra kuriama kitos, kiekvienas tekstas išsiskleidžia kaip citatų sankirtos erdvè, yra kuriamas iš kultūrinio (socialinio) teksto ir egzistuoja neatsietas nuo visuomenès ir istorijos. Todèl tekstas suprantamas ne kaip ženklas, bet kaip procesas, kai (skaitant) kuriamas ženklas ${ }^{7}$. Šiuo intertekstualumo procesu domëjosi ir kiti poststruktūralistai (R. Barthes'as, M. Foucault): „Knygos ribos niekuomet nėra aiškiai apibrezžtos: anapus antraštès, pirmujuc eilučių, galutinio taško, anapus jos vidinès struktūros ir autonomiškos formos ji pačiumpama nuorodu i kitas knygas, kitus tekstus, kitų sistemų sakinius: ji yra kaip mazgas tinkle. ${ }^{8}$ R. Barthes'as visus tekstus, kalbas ịvardija kaip sudarytas iš kitu tekstu, nuorodų, citatu (ankstesniu ir šiuolaikinių kultūros kalbų). „Intertekstualumas, ị kurị įtrauktas bet koks tekstas, nes jis pats yra kokio nors kito teksto tarptekstis, negali būti painiojamas su kokia nors teksto kilme: ieškoti kūrinio „šaltiniu“", „ittaku“” - tik igyvendinti perimamumo [filiation] mita. ${ }^{.9}$ Ivardinta intertekstualumo samprata, kalbant apie kūrybinį konteksta, sietina su nesąmoningu citavimu, atsirandan- čiu iš subjektyviụ paties menininko patirčių, žinių bei konteksto, kuriame jis yra.

Intertekstinè prieiga analizuojant adaptacijas neretai balansuoja ant šios ribos, kada „iššifruojami“ intertekstai gali būti sąmoningai parinkti kūrèjų, nesąmoningai ịsiterpę iš jų kūrybinès patirties bei paties interpretuotojo patirtys, leidžiančios pastebèti galbūt dar kitus intertekstus. Analizuojant adaptacijas, dažnai nepriklausomai nuo pasirinkto tyrimo aspekto pasitelkiama naratyvinè analizė ir / arba intertekstinè perspektyva.

Adaptaciju studiju atstovai, susikoncentravę ties literatūros kūriniu perkèlimu i kitas medijas tyrimais (A. Dudley, Th. Leith, L. Hutcheon ir kt.), galima teigti, dažnai atsisako platesniosios sampratos, daugiau dèmesio skiria tik tekstiniams ryšiams. Tyrejjams svarbi prancūzų literatūrologo Gerardo Genette'o pasiūlyta tekstinių santykių klasifikacija, kuria dažnai remiamasi, kai siekiama suklasifikuoti adaptacijas, kurti naujas tipologijas. Roberto Stamo nuomone, intertekstinè prieiga nekuria hierarchiju, o juk su jomis neretai susidurdavo tyrinètojai bei suvokejai. R. Stamas kalba apie dialoginius ryšius sisteminančią Genette'o transtekstualumo koncepciją - jo sukurtą analitinį aparatą kuris leidžia ekranizacijas laikyti „daugiasluoksniu intertekstinių derybų rūšimi“ ir priskirti jas prie hipertekstinius ryšius kuriančiu tekstų, "transformuojančių" literatūros kūrini atrankos, papildymo konkretizavimo ir aktualizacijos operacijomis. Ekranizacija čia pripažisstama vèliau sukurtu antruoju, bet ne antriniu (!) tekstu (hipertekstu), kaip pagrindini dialogo dalyvi nurodančiu literatūros kūrinị (hipoteks- 
tą). Ir tam, kad dialogas ivyktu, kad ekranizacija būtų suvokiama kaip ekranizacija, skaitytojo sąmoneje turi egzistuoti kitas, anksčiau sukurtasis tekstas ${ }^{10}$.

Literatūrologo Michaelio Riffaterre'o teigimu, „skaitytojas privalo turèti kompetenciją apčiuopti agramatizmus - kito teksto įsiveržimo ženklus - ir prasminius tarpus - citatas be nuorodu ir pan. Dviejų tekstų saitą M. Riffaterre'as vadina interpretante, kurią apibrèžia kaip žodi arba teksto fragmenta, atsiradusi dvieju semantinių arba formalių asociacijų sekų susikirtimo vietoje."11 Riffaterre'as intertekstualumą apibrèžia kaip konkretaus santykio tarp skaitomo teksto ir kitu anksčiau ar vèliau sukurtų kūrinių (t. y. intertekstų) suvokimą. Jis išskiria du intertekstualumo raiškos tipus - privalomaji ir atsitiktinį. Privalomojo atveju, tai skaitytoją supažindinanti tekstinė informacija, kuri literatūros kūrinyje pateikiama kabutėse, kitoje medijoje, pavyzdžiui, kine - subtitrais, jos net ir nežinant cituojamo ar adaptuojamo kūrinio ignoruoti tiesiog neįmanoma. Atsitiktiniais jis įvardija teksto nuorodas, kurių raišką nulemia skaitytojo, suvokejjo žinios bei kompetencija. Panašiai intertekstualumą apibūdina R. Barthes'as: „,<..> kita vertus, jis visas suaustas iš citatų, nuorodų, sąšaukų - ankstesnių ar šiuolaikinių kultūrinių kalbų (o kokia kalba nèra tokia?), kurios ji kiaurai skrodžia sukurdamos milžinišką stereofoniją"12.

Intertekstualumas, intertekstinès analizès prieiga adaptacijų analizavimo praktikoje labai reikšminga ir pasireiškia izvairiais būdais. Nuo adaptuojamo literatūros kūrinio ar kelių kūrinių junginio kaip interteksto naujame kūrinyje, kitoje medijoje (teatre, kine ar kt.) sukurtoje adaptacijoje iki rašytojo ar režisieriaus pasitelkiamų savosios kūrybos intertekstų ar šiuo metu itin tyrinejjamo reiškinio adaptacijų kaip intertekstų kitose adaptacijose. Kaip pavyzdi galima prisiminti žymujji Alfredo Hitchcocko filmą „Psichopatas" (1960), sukurtą pagal Roberto Blocho romaną (scenarijaus autorius Josephas Stefano), kuris praejjus keliems dešimtmečiams buvo adaptuotas režisieriaus Guso Van Santo to paties pavadinimo filme. Šiuo atveju svarbu tai, kad buvo adaptuojamas ne tik R. Blocho romanas, bet būtent pagal ji sukurtas ir A. Hitchcocko režisuotas scenarijus. Vienas naujesnių pavyzdžių - prancūzų režisieriaus Luca Guadagnino filmas „Didesni purslai“ (2015), kuris yra Jacques'o Deray'aus filmo „Baseinas“ (1969) adaptacija. Ir šiuo atveju analogiškai buvo adaptuojamas ne tik pirminis kūrinys romanas, bet ir jo ekranizacija. Klasifikacijose tokio pobūdžio adaptacijoms dažnai vartojamas perdirbinio terminas. Panašūs tyrimai, intertekstų paieškos skirtingose to paties kūrinio adaptacijose vyksta ir kitose medijose. Kalbant lietuviško konteksto pavyzdžiais, galima paminèti „Hamleto" adaptacijas, sukurtas skirtingų kartų režisierių: E. Nekrošiaus, O. Koršunovo bei V. Bareikio. Intertekstualumo reiškinys ne mažiau svarbus tyrinejjant ir vadinamąsias „adaptaciju grandines", kurias, anot Th. Leitcho, sudaro antrinès, tretinès ir t. t. adaptacijos (pavyzdžiui, filmas sukurtas pagal opera, opera - pagal pasaką) $)^{13}$. Taip pat, kai to paties kūrinio naratyvas adaptuojamas, transformuojamas jau ne keliose medijose, o daug plačiau: nuo dramos, 
šokio, muzikinio, lèlių teatro iki vaidybinio kino, animacijos, TV serialų bei teminiu parku, komiksu, "gifų", kompiuterinių žaidimų ir t. t.

\section{Intermedialumas}

Anot I. Melnikovos, „intertekstualumo teoriniai pamatai nulèmé intermedialumo teorinès minties ir ja grindžiamos ryšiu klasifikacijos specifiką ${ }^{\prime 14}$. Intermedialumo terminas gana naujas, plačiai pradètas vartoti ir įsitvirtinęs vos prieš kelis dešimtmečius. Intermedialumo sąvoką savo teoriniuose tekstuose, straipsniuose išsamiai analizuoja W. Wolfas, W. Bernhartas, I. O. Rajewsky, Ed. F. Chapple, Ch. Kattenbelt ir kt. Galima vienareikšmiškai teigti, visų skaitytų autorių tekstuose intermedialumo sąvokos autoryste priskiriama vokiečiu mokslininkui Aage'ui A. Hansen-Löve'ui jo straipsnyje „Intermedialumas ir intertekstualumas: žodinio ir vaizduojamojo menų koreliacijos problema." Aptardamas šio termino ištakas, Jensas Schröteris intermedialumo kilmę sieja su sąvoka intermedia, turinčią daug ilgesnę istorija, jau $1812 \mathrm{~m}$. ją pavartojo anglu poetas, literatūros kritikas Samuelis Tayloras Coleridge'as. Terminas intermedia, J. Schröterio įsitikinimu, paplito ir patyrè atgimimą $1960 \mathrm{~m}$. kartu su susibūrusiu tarptautiniu menininku judejimu "Fluxus", savo veikloje bandžiusiu susieti skirtingas meno sritis bei technikas. Analizuodamas intermedialumo sąvokos susiformavimo istoriją, ne vienas teoretikas prisimine XIX a. Richardo Wagnerio pasiūlytą gesamtkunstwerk (menu sintezès) idejją. Kita dalis tyrëjų intermedialumą kildina iš J. Kris- tevos vartojamo ir apibrěžiamo intertekstualumo termino.

Siejant su J. Kristevos intertekstualumo apibrèžimu, „intermedialumas plačiaja prasme suprantamas kaip realus ar virtualus medijos ribu peržengimas skirtingu medijų dialogas, apimantis visus įmanomus ryšius ${ }^{\prime 15}$. Paprastai intermedialumas siejamas su literatūros, teatro, muzikos, kino, dailès, fotografijos ir (ar) kitų medijų ribų peržengimu kūrinyje. Teoriniuose darbuose išplètojama pati intermedialumo sąvoka, kuriamos naujos sistemos, grupès, kuriomis bandoma sistemiškai kalbèti apie kokią nors intermedialumo raišką. Daugiausia naudojamasi W. Wolfo ir I. O. Rajewsky pasiūlytomis klasifikacijomis: „<...> iš intermedialumo perima esminę perskyrą plačiająa ir siaurajją intermedialumo sampratas. Intermedialumo atveju plačioji samprata (Barthes'o ir Kristevos) tiesiog fiksuoja tekstų dialogą kaip reiškini, kurio įtakos negali išvengti joks tekstas <...>. Intermedialumą plačiąja prasme Wolfas ir Rajewsky apibūdina kaip atvirą ar implikuotą medijos ribų iveikima, kurianti ivairialypes ir klasifikuotinas sąsajas tarp medijų. Intermedialumas siauraja prasme savo ruožtu suvokiamas kaip ne visada atviras, bet pačių tekstų kuriamas ir įreikšminimo procesus veikiantis ryšys tarp medijų.. ${ }^{\prime 16}$

I. O. Rajewsky straipsnyje „Intermedialumas, intertekstualumas ir remediacija" išskiria dvi pagrindines intermedialumo perspektyvas: diachroninę ir sinchroninę. Diachronine ivvardijama istoriniu pokyčiu - naujuju medijų atsiradimo, jų santykio su senosiomis, skirtin- 
gų mediju susikirtimo kūrinyje - analizè. Sinchroninè perspektyva apima skirtingu medijų susikirtimus konkrečiame meno kūrinyje, arba kitaip sakant - jame vykstanti medijų dialogą ${ }^{17}$.

W. Wolfas intermedialumą siūlo skirstyti i ekstrakompozicini ir intrakompozicini. Ekstrakompozicinis intermedialumas suvokiamas kaip bendrojo pobūdžio santykiai tarp medijų. Ji išskaido i dar du tipus, vienas ju - tansmedialumas, kuriuo laikomi su aptariamos medijos savybėmis nesusiję reiškiniai, randami ir kitose medijose (pavyzdžiui, tas pats naratyvas literatūros kūrinyje ir muzikoje, taip pat čia gali būti priskirtini ir archetipiniai motyvai ir kt.). Kitas intermedialusis perkèlimas, kuris aiškinamas kaip vienos medijos transformavimas i kitos medijos tekstą (pavyzdžiui, romano virtimas opera, literatūros kūrinio ekranizacija kine ir kt.). Intrakompozicinis intermedialumas (arba kaip dar teigiama, intermedialumas siauraja prasme) - kelių formų jungimas semiotinèje teksto struktūroje, kurioje kiekviena iš šių formų dalyvauja kuriant teksto struktūrą. Intrakompozicini skaido ị du smulkesnius tipus, pagrindiniai - multimedialumas ir intermedialioji nuoroda. Multimedialumas ivvardijamas kaip atvira formų jungtis (pavyzdžiui, literatūrinio kūrinio tekste - piešinys, spektaklyje fotografijos ar kino kadrai) ${ }^{18}$. Rajewsky ši procesą vadina medijos keitimu, kurio metu medijos tampa sintetinemis. Wolfo siūlomas tipas intermedialioji nuoroda (ją suskaido i smulkesnius tipus) - tai nurodymas i kitą mediją ar jos tekstą nenaudojant jos raiškos priemonių.
Adaptacijos studijų kontekste intertekstinė prieiga, intermedialumas kaip sąvoka ir kaip reiškinys jau kelis dešimtmečius yra neatsiejami nuo atliekamu tyrimų - analizuojamų adaptacijų procesų. Studijose naudojamasi tiek platesne šių sąvokų apibrèžtimi, tiek iš jos kildinamais smulkesniais tipais bei klasifikacijomis. Šios teorinès iž̌valgos analizuojant adaptacijas leidžia kalbèti apie naujame kūrinyje fiksuojamas nuorodas ne tik ị literatūros kūrinius, bet ir ị kitus kontekstus.

Intermedialumas adaptacijose pasireiškia bent keliais sluoksniais: mediju jungtyse, transformacijose, pasižyminčiose ne tik vienašališku ryšiu su literatūra (kinas), bet ir grižtamuoju ar vedančiu per tekstą-naratyvą iš vienos medijos i kitą iš teksto i filma, teatro spektaklį, animacinį filmą kompiuterini žaidimą ar kt. Medijų jungtis, vykstanti kūrinyje, būdinga ir tam tikroms adaptacijoms, kurios pirminị literatūros tekstą naudoja kaip aliuziją naujam „filmo tekstui“. Pavyzdžiui, A. Pacino filmas „Ričardo beieškant” (1996), kuriame sumaišomas dokumentinis filmas su nufilmuota W. Shakespeare'o „Ričardo III" dramine versija.

Intertekstualumas, intermedialumas, apimantis tekstų bei medijų tarpusavio susikirtimus / ryšius, adaptacijų studijose kalba apie to paties naratyvo galimybę cirkuliuoti skirtingose medijose, kontekstų itakas. Suteikia galimybę kalbèti apie adaptaciju kontekste vykstanti besiformuojančių ryšių procesą. Intermedialūs tyrimai, apimantys daugybę to paties teksto (naratyvo) transformacijų, leidžia ištirti îvairius adaptacijos proceso aspektus. 


\section{DEKONSTRUKCIJA}

Vyraujančiu kūrinio reikšmių paneigimas ir interpretaciju dialogas

Poststruktūralizmas siejamas su dekonstrukcijos (kūrinių analizės) metodu, arba kai kuriais atvejais terminai poststruktūralizmas ir dekonstrukcija vartojami kaip sinonimai. Dekonstrukcija tam tikra prasme paradoksų mokslas - analizès metodas. Bendriausias teksto dekonstravimo būdas - siekis pateikti kuo daugiau perskaitymo būdų. Taikant dekonstrukcijos prieiga paprastai atliekama ir detali (formali) pirminè analizè, būdinga ir daugeliui kitu metoduc. Dekonstrukcijai svarbus oponuojančios interpretacijos sukūrimas. Vienintelè interpretacija negali būti teisinga. Ieškoma paraščiu, ittrūkių ir kitų mažiau pastebimų teksto fragmentų. Tekstų vertinimai kaip nepabaigiamas dialogas (susiję su M. Bachtino idejomis).

Dekonstrukcijos esminius dalykus ivardijo ir savo darbuose ${ }^{19}$ apibrèżè Jacques'as Derrida. J. Derrida kūrinio supratimą įvardija kaip nuolatini reikšmès atidèliojimą. Šią visada slenkstinę prasmès būseną Derrida ịvardija sąvoka différance (skirsmas), paremtą dviem veiksmažodžio différer reikšmėmis: „1) skirti, daryti skirtumą; 2) uždelsti, užlaikyti, atidè-

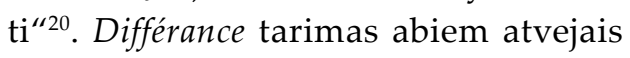
nesiskiria, skirsmą suteikia užrašymas. Abu žodžiai reiškia procesualumą, tik differance yra tarsi "pirmapradiškesnis“, jis yra bet kokio difference (skirtumo, skirties) „,kilmè", „,̌̌altinis“, jo galimybès sąlyga. Skirsmas žymi skyrimo-uždelsimo produkavimą, per kuri ir randasi reikšmė (čia Derrida tęsia Saussure'o teiginį, esą kalboje svarbūs vien skirtumai, taigi reikšmė gali rastis tik iš elementu skirtumų ${ }^{21}$.

Derrida siūlomas skirsmas apima ir skirtumą ir sąsajas. Savo idejas Derrida argumentavo pasitelkdamas S. Freudo esė, kurioje aiškino, kaip i pasąmonę i̇rašomi sąmonès impulsai (juos palygino su vaškiniame bloknoto paviršiuje išnykstančiu ịrašu). Derrida siūlo praeities apraiškoms dabartyje vartoti peddsako sąvoka, kuri, kitaip nei semiotinis ženklas, apima ir būtaji laiką. Derrida dekonstrukcijoje prasmès pažinimas yra iliuzinis, jis negali turèti savo pastovaus prasmès centro, kuris istoriškai buvo ženklinamas įvairiausiomis sąvokomis (eidos, arche, telos, energija, dievas ir kt. $)^{22}$. Šios bendrosios sąvokos, nurodančios abstrakčias, viską apimančios prasmès paieškas, parodo, kad net ir smulkesniame kontekste, pavyzdžiui, meno kūrinyje, tekste galutinès ir nekintamos reikšmès būti negali.

Pastovios reikšmès, reikšminio centro - simbolio - klausimas neretai buvo aktualizuotas adaptacijos studiju autoriu tekstuose. Iš pradžiu buvo bandoma iteigti, kad adaptuojamame kūrinyje egzistuoja kažkoks sunkiai apčiuopiamas, bet kažkokiu būdu jaučiamas elementas, kuriam taikè įvairias sąvokas (A. Bazinas vadino dvasia, George'as W. Lindenas vadino kūrinio stiliumi). Sekdami poststruktūralistais arba galbūt naudodamiesi dekonstrukcijos metodu adaptacijų atstovai - tyrinètojai ir kūrejjai - pamažu atsisakè to pagrindinès reikšmès centro, 
simbolio, vienpusiško žiūros taško, kuris gana ilgai dominavo. Dažnai šis atsargus požiūris ị kūrinį, neliečiamumo nuostata lydèjo klasikinès literatūros kūrinius, turinčius nusistovejjusias interpretacijas, sistemiškai nurodančias esminius kūrinio dalykus, reikšmes. Tokiu būdu po truputi pradejo daugèti adaptaciju, pateikiančiu savąsias versijas, pasiūlančiu visiškai kitokių žiūros taškų: pavyzdžiui, žvilgsni sukoncentruojant i pirminiame tekste visiškai šalutini elementa, keičiant kūrinyje pasiūlytas aplinkybes, i̇vedant naujus personažus ar kitus elementus.

Anot kinotyrininko Dudley Andrew, poststruktūralizmo atstovai palaiko tekstu perrašymo galimumo skirtingai epochai idejją. ${ }^{23}$ Adaptacijų studijų lauke, kalbant apie kino / teatro medijas kūrinio (teksto): pokyčiai, atnaujinimai ir siekis suaktualinti yra svarbūs (ypač šiuolaikiniame kontekste), nes tokios adaptacijos, kaip ir literatūros studijos interpretacijos kalba šiuolaikiniam žmogui. Žymiai anksčiau A. Bazinas, savo žymiajame straipsnyje, adaptacijų tam tikrame atskaitos taške prisiliete ir prie šio klausimo, jo teigimu, adaptacijos ( $k \bar{u}-$ rinio „santraukos“ kitoje medijoje) turi ir reikšmingą misiją kūrinio atžvilgiu, t.y. ji parodyti, paskatinti ji permąstyti tiems žmonèms, toms masėms, kurios galbūt nèra įdèmiau susidūrusios su konkretaus autoriaus kūryba bei ji palydinčiais kontekstais.

Anot poststruktūralistu, Derrida idèjos, viskas yra suprantama kaip tekstas visa mūsų patirtis yra tekstinè. Būdingas pantekstualizmas, nieko nèra, kas neegzistuotų kaip tekstas. Mūsų žvilgsnis visada „itekstintas“, ideologiškas, sub- jektyvus. Dekonstrukcija, kaip iprasta kitiems metodams, neturi aiškios schemos, kaip reikètu analizuoti, interpretuoti kūrini, neretai siūlomas tam tikras kūrinio išskaidymas i gabaliukus, fragmentus ir ju interpretavimas nesiejant tarpusavyje. Būdingas nukrypimas ị visus įmanomus tekstus, reikšmes neieškant tikslių, susisiejančiu prasmių, o tiesiog neaprèpiama laisva digresiju erdvè. Nesiekiama tų pastebètu reikšmiu jungti i didesnius modelius. Atskleidžiamas ne teksto vientisumas, o daugiareikšmiškumas - „reikšmių išsprogimas“. Jokios galutinès struktūros poststruktūralistai, priešingai nei struktūralistai, atrasti nenori, ieškoma daugybiškumo. D. Andrew, kalbėdamas apie adaptacijas, pasitelkè A. Bazino „krištolinio sietyno ir žibintuvèlio metaforą": kūrinys suvokiamas kaip daugiabriaunis sietynas - daugiareikšmis tekstas, o kinas (ar kita medija, kurioje adaptuojamas / interpretuojamas kūrinys) - kaip žibintuvèlis, apšviečiantis kurią nors jo dalelę ir ją paverčiantis žiūros tašku, naujo kūrinio perspektyva. Abiem atvejais nepretenduojama iškart pateikti, „išinterpretuoti“" visas kūrinio reikšmes, o kalbama apie fragmentiška, be abejo, itin subjektyvų, kūrinio dalių interpretavimą.

Dekonstrukcijai svarbu identifikuoti perskaitymo būdus, sukurti oponuojančias interpretacijas. Tikima, kad nėra vienintelès teisingos interpretacijos. Ieškoma paraščiu, teksto įtrūkių, nuorodų ir kitų mažiau pastebimų detalių. Skirtingi teksto vertinimai, analizès kuria dialogini santyki. Tai metodas, analizès prieiga, kuriai būdingas paradoksalu- 
mas - pavyzdžiui, siekiama surasti opoziciją jau issitvirtinusiai interpretacijai, tačiau ją suradus, pirmoji nèra paneigiama kaip negalima / neteisinga, tik parodomas jos nestabilumas.

Poststruktūralistai neatsisako struktūralistų plètotos idèjos, kad objekto tapatybè nustatoma per skirti su tuo, kas jis nèra, tačiau akcentuoja šiai skirčiai būdingą vieną negatyviąją pusę bei neigia šių skirčių-opoziciju nekintamumą. Binarinès opozicijos, jų realus negalimumas, galima sakyti, kaip literatūros kūrinio interpretacijose, taip ir režisieriui, kuriant adaptacija, yra griaunamos pasitelkiant ịvairias režisūrines strategijas. Tokiems procesams neretai pasirenkami kūriniai, turintys nusistovejusią juodabalta, gera-bloga pozicija, kurią galima paneigti atnaujinant, suaktualinant, pasiūlant naują permąstymo / žiūros tašką.

Reikia pažymèti, kad kino adaptacijų kontekste dekonstrukcija kaip reiškinys ir kaip sąvoka reiškiasi dviem būdais. Pirmuoju atveju tai minètas literatūros kūrinio interpretavimas ir perkèlimas i kitą mediją, kai griaunamos vyraujančios interpretacijos (režisieriaus kardinaliai keičiamas kūrinio žanras, pateikiama prieštaringa jo versija). Pavyzdžiui, D. Andrew savo pateikiamoje klasifikacijoje taip pat kalba apie dekonstravimo procesus. Autoriaus ivardintam susikirtimo (intersection) adaptaciju tipui priskirtini kūriniai turètu priešintis pirminiam tekstui, dekonstruoti $\mathrm{ji}$, keisti kontekstą, pateikiamus požiūrius, reikšmes, kurti vizualiai prieštaringa, kontrastingą naują tekstą. Kitaip sakant, daugelis adaptaciju tyrejų, bandžiusių idiegti tipologijas, susisteminti savo tiriamuosius objektus, naudojasi dekonstrukcijos sąvokos ypatybe - prieštaringumu. Dekonstrukcijos terminas dažnai patenka i besipriešinančių pirminiam tekstui adaptaciju apibrèžtis.

Antruoju atveju kalbame apie dekonstrukcijos samprata, paremtą idèja, jog dekonstruoti - kažką „išardyti“, pavyzdžiui, parodyti (su)kūrimo mechanizmus. Turbūt detaliausios adaptaciju klasifikacijos kūrejas Th. Leichas i savo tipologiją ittraukè adaptacijų tipa, ivvardintą metakomentaro arba dekonstrukcijos sąvoka (metacommentary or deconstruction). O toki savo sprendimą pagrindè S. Jonze'o filmo „Adaptacija“ (2002) pavyzdžiu - šiame filme rodomas itin problemiškas tekstų kūrimo procesas, rodomas tiek pirminio teksto - knygos Orchideju vagis - rašymas, tiek scenaristo bandymas pagal ją sukurti adaptaciją.

\section{IŠVADOS}

Adaptacijų studijose tyrinėjamų objektu, reiškinių analizès prieigos dažniausiai atsiremia $\mathfrak{i}$ tekstinius, naratyvinius ryšius tarp pirminio teksto ir adaptacijos bei santykius tarp skirtingu medijų. Analizuojant adaptacijas, ieškant mokslinių prieigų, neišvengiamai susi- duriama su literatūrologų diktuojamomis teorijomis, tuo metu vyraujančiais metodais, neretai kylančiais iš filosofinių, bendrosios meno estetikos klausimų, judejjimų. Būtent čia kino teoretikai (adaptaciju studiju pionieriai) bei kiti mokslininkai, tyrinejjantys adaptaciją, 
ieško įrankių, galinčių „,atrakinti“ adaptacijas, nes šiuose tyrimuose medijos specifika, jos metodai susijungia su kita medija ir jos metodologijomis bei analizès principais.

Poststruktūralizme R. Barthes'o išgryninta „autoriaus“ mirties idejja turejo didelę ittaką adaptacijų atstovams - kūrejams ir teoretikams. Autoriaus galios, jo kaip reikšminio centro atsisakymas kitų medijų atstovams suteikė daugiau laisvės konkrečios medijos kūrybinių sprendimų, formų raiškai. Buvo „išjudinta" nusistovejusi adaptacijų hierarchijos piramidè, kurios viršuje - literatūros tekstas ir jo autorius, i kuri tradiciškai privalu atsižvelgti. Rašytojo-autoriaus pozicijos pokyčiai lèmė ir prasidèjusius adaptacijos analizès pokyčius, kai buvo pradèta ieškoti ir kitų metodų, prieigu, ne tik vienašališko palyginimo su pirminiu tekstu.

Adaptacijos studijoms itin svarbus jau ankstyvųjų poststruktūralistų atliktas kūrinio ,atvèrimas" arba išlaisvinimas iš uždaro reikšmių lauko (susieto su kūrinio autoriumi, laikotarpiu, vieta). Kūrinio interpretavimas suvokiamas kaip subjektyvus, bet priešingai nei anksčiau, šis bruožas neturi negatyvios konotacijos.

Dekonstrukcijos metodo, požiūrio i kūrinį kaip daugiareikšmi, nuolat kintantị, veikiamą ịvairiausių kontekstų susi-

\section{Literatūra ir nuorodos}

1. Simone Murray, The Adaptation Industry: The Cultural Economy of Contemporary Literary Adaptation. New York: Routledge, 2012, p. 30.

2. Thomas Leitch, Film adaptation Eits discontents. The Johns Hopkins University Press, 2007, p. 96.

3. Irina Melnikova, Adaptacijos studijos: literatūra formavimas, galima numanyti, lèmè drąsesnius adaptacijų kūrèjų bandymus perkurti, pasiūlyti naujas klasikinès literatūros kūrinių versijas. Tikètina, kad dekonstrukcinès idèjos galèjo paskatinti ir tam tikrą adaptacijų linkmę, kai atsisakoma anksčiau buvusių bandymų i kitą mediją perkelti didžiulès apimties kūrinius. Nepraleidžiant nè vieno teksto elemento, kai kurių kūrinių atžvilgiu toks elgesys sukurdavo pagreitinto, fragmentiško „prabègimo“" per kūrinį ispūdì, kuris atrodo kaip fonas ar tiesiog atpasakojimas, o ne naujas, išbaigtas, visapusiškas kūrinys. Vietoje to, pradèta dažniau koncentruotis i tema, aspekta, kuri adaptacijos autorius siekia aktualizuoti. Intertekstualumo ir intermedialumo susiformavimas ị adaptacijų studijų lauką inešè tuos reikalingus, tiesiog būtinus metodologinius įrankius, kuriems prieš tai galbūt nebuvo tikslios alternatyvos, nors patys procesai, tekstų cirkuliacijos viename kūrinyje, mediju junginiai neišvengiamai egzistavo jau daug anksčiau.

Poststruktūralistų pasiūlytos intertekstualumo, intermedialumo sampratos adaptaciju studijose naudojamos tiek plačiąja, tiek siauresniąja, konkretesne prasme. Intertekstualumo termino, reiškinio autorių idejos, galima teigti, yra esminis daugumos adaptaciju klasifikacijuc pamatas.

versus kinas - vertimas ar dialogas? Colloquia 28, 2012, p. 33.

4. Gabrielè Labanauskaitè, Naratyvo konstravimo principai šiuolaikinèje dramaturgijoje. 2013, p. 12. Prieiga per internetą: $l m t a . l t / g e t . p h p ?$ item $=f \mathcal{E} i d=$ 15162 [žiūrèta 201801 16]. 
5. Hendrik Wagenaar, Meaning in Action: Interpretation and dialogue in policy Analysis. M. E. Sharpe, 2011, p. 216.

6. Irina O. Rajewsky, Intermediality, Intertextuality, and Remediation. Intermédialités 6, Automne 2005, p. 48.

7. Irina Melnikova, Intertekstualumas: teorija ir praktika. Vilnius: Vilniaus universiteto leidykla, 2003, p. 19.

8. Michel Foucault, The Archeology of Knowledge. London: Tavistock Publications, 1972, p. 23.

9. Roland Barthes, Nuo kūrinio prie teksto. XX amžiaus literatūros teorijos. Vilnius: Lietuvių literatūros ir tautosakos institutas, 2011, p. 125.

10. Irina Melnikova, Literatūros (inter)medialumo strofos, arba žodis ir vaizdas. Vilnius: Vilniaus universiteto leidykla, 2016, p. 124.

11. Michael Riffatterre, Semiotics of Poetry. Bloomington: Indiana University Press, 1978, p. 81-86.

12. Roland Barthes, Nuo kürinio prie teksto, p. 125.

13. Thomas Leitch, Film adaptation Eits discontents. The Johns Hopkins University Press, 2007, p. 120.

14. Irina Melnikova, Literatūros (inter)medialumo strofos, arba žodis ir vaizdas, p. 33-34.
15. Irina Melnikova, Intermedialumo žemėlapis. Colloquia, ISSN1802-3737, p. 20.

16. Irina Melnikova, Literatūros (inter)medialumo strofos, arba žodis ir vaizdas, p. 33-34.

17. Irina O. Rawesky, Intermediality, Intertextuality, and Remediation. Intermédialités 6, Automne 2005, p. 46-47.

18. Werner Wolf, Intermediality Revisited: Reflections on Word and Music Relations in the Context of a General Typology of Intermediality. Prieiga per internetą: <https://cursointermidialidade.files. wordpress.com/2014/08/wolf.pdf >

19. J. Derrida knygos Apie gramatologija ir Raštas ir skirtumas (1967).

20. Jacques Derrida, Struktūra, ženklas ir žaismas humanitarinių mokslų diskurse. XX amžiaus literatūros teorijos. Vilnius: Lietuvių literatūros ir tautosakos institutas, 2011, p. 150.

21. Ten pat. p.150.

22. Ten pat. p. 206.

23. Dudley Andrew, Concepts in Film Theory. New York: Oxford University Press, 1984, p. 95.

24. Jacques Derrida, Dissemination. London, New York: A\&C Black, 2004, p. 32. 